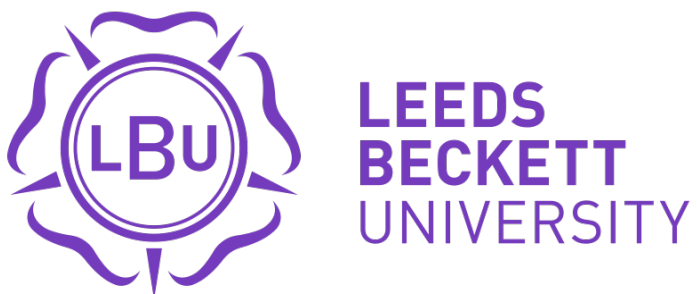

Citation:

Willis, P (2015) Public relations, passive aggression and critical social auditing: Reflections on organisational inaction in stakeholder engagement. Journal of Public Affairs, 15 (2). 220 - 226. ISSN 1472-3891 DOI: https://doi.org/10.1002/pa.1522

Link to Leeds Beckett Repository record:

https://eprints.leedsbeckett.ac.uk/id/eprint/1231/

Document Version:

Article (Accepted Version)

The aim of the Leeds Beckett Repository is to provide open access to our research, as required by funder policies and permitted by publishers and copyright law.

The Leeds Beckett repository holds a wide range of publications, each of which has been checked for copyright and the relevant embargo period has been applied by the Research Services team.

We operate on a standard take-down policy. If you are the author or publisher of an output and you would like it removed from the repository, please contact us and we will investigate on a case-by-case basis.

Each thesis in the repository has been cleared where necessary by the author for third party copyright. If you would like a thesis to be removed from the repository or believe there is an issue with copyright, please contact us on openaccess@leedsbeckett.ac.uk and we will investigate on a case-by-case basis. 


\section{PUBLIC RELATIONS, PASSIVE AGGRESSION \\ AND CRITICAL SOCIAL AUDITING: \\ REFLECTIONS ON ORGANISATIONAL INACTION IN STAKEHOLDER \\ ENGAGEMENT}

\section{Introduction}

This article explores issues associated with organisational governance in the context of stakeholder engagement. It argues that both public relations research and practice have yet to address systematically the challenges inherent in this area, particularly how organisations exert power over stakeholders. Prompted by a consideration of the situational theory of power put forward by the sociologist Steven Lukes (2005) the paper introduces the concept of passive aggression to public relations practice. This is cited as an example of a wider phenomenon which the author calls dark dialogue.

The insights generated by these new conceptual perspectives are used to highlight how theoretical approaches in the PR field that seek to understand and promote the role of dialogue in organisational-stakeholder relations face an empirical challenge. That is, the practices designed by organisations to deliberately suppress dialogue with stakeholders are less susceptible to observation than dialogue itself. This insight is then used to highlight the limitations of what has been traditionally termed as social auditing. Indeed, it is suggested that public relations and social auditing practice share the same myopic tendencies when it comes to assessing how organisations behave towards their stakeholders. The article then advocates a role for public relations practitioners to instil critical thinking about power into a reconfigured social auditing process. It ends by suggesting that action research provides a methodological framework which has the potential to bring PR academics and practitioners together to work through the complexity that surrounds these issues.

\section{The realm of covert organisational governance}

Gregory and Willis (2013) note that stakeholder engagement falls under the rubric of covert, as opposed to overt, organisational governance. This conceptualisation is based on the idea that stakeholder engagement should not just be shaped and codified by rules, regulations and laws. Rather, governance obligations in this area should extend beyond organisations being legally compliant and should be driven instead by how organisations enact values based behaviours that stakeholders regard as fair and appropriate.

Given that values are self-determined and chosen by an organisation it is legitimate for stakeholders to judge its performance against them. In this regard, values represent a publicly declared 'contract' that an organisation has with its stakeholders on how it will fulfil its mission and purpose: essentially, they have the potential to become a declaration of the principles that guide its decision-making and behaviour. The actual values an organisation lives and operates by should shape its culture, frame the interactions it has with stakeholders and govern ultimately how it acts. If an organisation does not live by the values it purports to then stakeholders are entitled to question its authenticity.

In this context effective governance therefore becomes about ensuring that behaviour and decision-making across the organisation align with a set of values deemed appropriate by stakeholders (covert accountability), as much as by regulatory and legal norms (overt accountability). This requires self-governance, self-reflection and self-restraint on the part of 
the organisation. Furthermore, the process of alignment should be managed through a dialogue that takes place between an organisation and its stakeholders. In this context dialogue serves two purposes. First, it is the process through which values are negotiated and agreed. Second, dialogue itself becomes a way of demonstrating values in action.

\section{Public relations, dark dialogue and organisational governance}

Dialogue is a key concept in a range of theoretical frameworks in the public relations field (Macnamara, 2012). These include excellence theory (Grunig et al 2002), the rhetorical theory of public relations (Heath et al, 2009) and Kent and Taylor's (2002) dialogic theory of PR. Dialogue is held to be important because of the role it plays in maintaining and developing relationships with an organisation's stakeholders, enacted through both interpersonal and mediated communication. From these theoretical perspectives dialogue becomes crucial to the governance of the organisation and its overall licence to operate.

Pieczka (2011) notes, however, that dialogue is still "poorly understood” (p. 119) in public relations and used marginally as evidenced by an absence of expert tools or spaces where it is practised routinely. The importance of dialogue to organisational governance raises additional questions, including how organisations assess and monitor their behaviour and actions in relation to stakeholders. Kent, Taylor and McAllister-Spooner (2008) identify five characteristics of dialogue that can be used to scrutinise performance. Of particular relevance to this study is their second feature, propinquity. This refers to an organisation's willingness to engage, as well as the recognition that people should be consulted in a timely and relevant way (Macnamara, 2012). Pausing to reflect on this point serves to highlight the difficulties associated with gauging an organisation's commitment to dialogue. Rather than just focussing on how dialogue is conducted by an organisation, consideration should also be given to those practices initiated by it that nullify dialogue and inhibit engagement by stakeholders. Such activity is framed in this article as dark dialogue, that is, the underbelly of the discourse that is said to smooth the relations between an organisation and its stakeholders. This idea complements the shadow imagery used to telling effect by Fawkes (2010) in her Jungian inspired discussion of PR ethics, another example of research in the field that seeks to explore the discipline's 'dark' aspects. This article's dark perspective on dialogue will now be examined in greater detail through a theoretical lens from outside of the public relations field.

\section{A situational theory of power}

Lukes' (2005) seminal analysis of power is helpful to public relations scholars concerned with the study of how organisations behave towards their stakeholders. Rather than focussing on the attribution of specific powers to actors, Lukes is instead interested in the situational exercise of power. To investigate this phenomenon he develops a conceptual map with four variables: issue scope, contextual range, intentionality and activity. His contextual and critical perspective on power generates key questions about the role of public relations in what Berger (2005) calls 'power over' (p. 15) relations in the stakeholder environment.

Each of the elements in Lukes' conceptual map contains relevant insights that can be used to gain a better understanding of the nature and reach of an organisation's power. It is the last element, however, that contains the most fruitful and specific insights for public relations in the context of this study. This is concerned with Lukes' discussion of the distinction between active and inactive power. He illustrates here that inaction, abstention and non-intervention 
can be forms of power. By doing so, he highlights that the features of organisations that make them powerful include those that render activity unnecessary.

This perspective prompts a reflection on the role of public relations inaction with regard to stakeholder engagement, or what might be more accurately called non-engagement. This could include the decision not to communicate (the silent treatment), delaying the release of information and intentional inefficiency (procrastination), or only responding to enquiries and requests through communication channels the organisation itself sanctions (ignoring people). This article argues that such non-activity by PR practitioners and others in the organisation is often a form of resistance to demands from stakeholders for adequate performance in particular social contexts, such as a company's consultation programme around a planning application for a new development. Furthermore, such sugar coated hostility can be veiled by actions that appear to be inclusive and empathetic to stakeholders while at the same time seeking to undermine them. A consultation event that is scheduled deliberately to disadvantage stakeholders is an example of this.

Psychologists (Lane, 2009) characterise such behaviour in people as passive aggression. It is proposed here that the term should also be applied to organisations and, more specifically, to particular forms of public relations practice. This leads to the creation of what can be regarded as a new sub set of dark dialogue. Its merit lies in reconfiguring what might initially be positioned as an unfortunate operational failing or oversight to a premeditated and covert form of stakeholder abuse. The insights this framing generates serve to move attention away from just considering what organisations do to engage with stakeholders, to what they don't do. The idea of passive aggression also serves to illustrate the empirical challenges inherent in relying on dialogue driven PR theories to assess an organisation's behaviour with stakeholders. Indeed, the practices designed by organisations to deliberately suppress dialogue with stakeholders are less susceptible to observation than dialogue itself.

\section{Inside out not outside in}

The need to actively engage with issues associated with organisational power is further justified given the attention accorded in public relations practice to the impact of stakeholder power on an organisation, at the expense of an active and inverse consideration of how the power of the organisation affects stakeholders (L'Etang and Pieczka, 1996; Berger, 2005; Edwards, 2006; McKie and Munshi, 2007). Assessing the power and influence of stakeholders is regarded as a key role for public relations practitioners given the strategic environmental scanning role they have been prescribed in organisations, most notably by Grunig and Repper (1992) as part of the development of the Excellence Theory of public relations. This perspective notes that given stakeholders represent the raison d'etre for public relations their impact on the organisation must be assessed and planned for.

This focus has led, however, to a troubling strategic imbalance. That is, a pre-occupation with the impact of stakeholder power on an organisation, with little reciprocal appreciation of how the power of the organisation affects others (Leitch and Neilson, 2001; Holtzhausen, 2007). This can lead to an emphasis on 'intelligence in' to an organisation as it seeks to respond to the challenges of the stakeholder environment rather than a more balanced approach that also considers the impact of an organisation's power on its stakeholders. Indeed, it is suggested that the absence of a symmetrical view of power in practice will inhibit the strategic role public relations can play in helping an organisation to self-govern and maintain its license to operate in a complex stakeholder environment. Engagement with critical thinking on power is 
important at a time when public relations scholarship needs to develop "a more justice-based, methodically sophisticated and socially relevant agenda” (McKie, 2010, p. 93).

In contrast to Excellence Theory, critical scholars in the PR field have highlighted the role that public relations has played in helping to enhance organisational power through the production of persuasive texts and strategic attempts to influence discourse. Berger (2005), for example, has noted how 'power over' (p. 15) relations are today conceptualised as hegemony and discusses the role of public relations in this non-coercive form of domination in which subordinated groups actively consent to and support belief systems and structures of power that do not serve their group interests. Edwards (2006) through Bourdieu's lens of fields, habitus and capital has also examined the power of public relations and its role in promoting “privileged organisational interests” (p. 229), while L'Etang (1996) notes that "only if practitioners engage with issues of power can they avoid charges of superficiality and the cynical exploitation of target audiences" (p. 105).

\section{Keeping 'good' company: shared limitations and blind spots}

The issues associated with power and governance that have been highlighted have a resonance that extends beyond public relations. Researchers have highlighted that the issue of power is an underlying theme in many of the current critiques of corporate social responsibility (CSR) by management scholars and is likely to dominate discussion about the development of the field in the years ahead (Blowfield and Murray, 2008; Newell, 2005; Blowfield, 2005; Bendell, 2004). They argue that corporate social responsibility, in terms of both theory and practice, has not been able to confront corporate power and that alternative approaches are required.

Implicit in these debates is the idea that CSR is not just about organisations seeking solutions for the social issues generated by their business operations and interests but should be concerned with a wider duty to act responsibly in their relationships with stakeholders. An organisation's social performance cannot be properly assessed unless consideration is given to how it furthers its own interests and affects the interests of others. That is, how does an organisation exhibit power over different stakeholders and - from the particular perspective discussed in this article - what role do practices such as passive aggression and other forms of non-engagement play?

\section{Social auditing: a case of arrested development}

Existing social auditing conventions ignore this element of corporate social responsibility performance despite the popular Triple Bottom Line (TBL) (Elkington, 1997) approach to company reporting which emphasises that corporate responsibility can be linked to how companies treat their stakeholders (Waddock, 2001). Indeed, Elkington warned that the social justice end of TBL auditing tends to be the area that is most overlooked by organisations.

Social auditing approaches have failed to address these challenges despite becoming a distinct research theme within corporate social responsibility (Freeman et al, 2010). Although its roots can be traced back to the 1940s, it was not until the late 1990s that social auditing began to gather momentum and gain a wider prominence (Davenport, 1997), as demonstrated by Elkington's (1997) popularisation of the TBL. Although the idea was first articulated by Spreckley (1981), Elkington's work sixteen years later persuasively promoted the need for 
companies to account for their financial, environmental and social performance and propelled the term into the management vernacular.

Being part of the wider CSR field means that social auditing should embrace its central tenet which is that companies owe a duty to society that stretches beyond shareholders (Jones, 1980) and should have a broad concern with the impact of their behaviour on society (Preston, 1988). Social auditing theorists should therefore both challenge the primacy of the shareholder group and recognise an explicit obligation for companies to be accountable to wider society, a perspective fired by Freeman's (1984) seminal work on stakeholders that sought to answer the question to whom should business be responsible? Indeed, Wood (1991) notes that Freeman's definition of stakeholders as those groups who can affect or are affected by the achievement of an organisation's purpose bought the "abstract idea called society closer to home" (p. 697) and articulated a world in which business and society are interwoven rather than distinct entities.

The aim of social auditing is to provide an insight into the social performance of an organisation and is based on the premise that the concept of CSR cannot be properly applied in managerial practice if its advocates are not able to develop reliable, systematic ways of translating CSR approaches into accountable measures (Freeman et al, 2010). As a result, it has a practice-orientated focus. Waddock (2001) highlights that two types of social audit have emerged: audits that seek to gauge external stakeholder perceptions of corporate practices and internal audits of the actual practices themselves to determine their impact on relevant stakeholders, as well as overall organisational performance.

Assessing an organisation's corporate social performance requires the examination of a wide variety of motives, behaviours and outcomes (Wood, 1991) and a particular consideration of values in action (Gregory and Willis, 2013). Today, the proliferation of reputational ratings purportedly linked to CSR criteria is illustrated by the Fortune 500 in the United States, Asian Business' Asia's Most Admired Companies', The Financial Times, Europe's Most Respected Companies and Management Today's Britain's Most Admired Companies, as well as a range of Best Company lists that feature not only large publicly listed companies but also small and medium sized enterprises (SMEs). These highlight how a range of organisations attach great importance to communicating the social and environmental effects of their economic actions to particular interest groups within society, as well as society at large. They also illustrate Elkington's view that in Triple Bottom Line auditing social justice tends to be the area that is forgotten.

The issues most often featured in these indices and in organisational reports on practice are community relations, product safety, training and education initiatives, sponsorship, charitable donations and the employment of disadvantaged groups. These fail to address the issue of power and how the organisation furthers its own interests and affects the interests of others. Today, in the wake of the global financial crisis which generated widespread economic, social and political dislocation there has been a renewed interest in the need for companies to prove they are responsible corporate citizens behaving in the public interest as levels of trust in business have plummeted (Bowen, 2008; Edelman, 2013).

\section{An image problem}

Public relations functional concern with managing key stakeholder relationships on behalf of the organisation should give it a unique perspective on these issues. Furthermore, if PR 
practitioners lead these debates and develop approaches that can aid organisational decisionmaking in this context it will serve to enhance the field's effectiveness, reinforce its association with social responsibility and boost its credibility as a management function within the organisation.

Public relations does, however, need to confront its own image problem in this arena. Key literature in the CSR field has to date equated public relations with spin and the 'glossy' communication of initiatives rather than a strategic management discipline that shapes the organisation's response to the social issues it generates (Blowfield and Murray, 2008; Friedman and Miles, 2006; Elkington, 1997). In short, PR is associated with presentation and communication rather than strategic counsel and the development of policy. This means that in the area of social auditing public relations is relegated to a technical role linked to the production and promotion of reports on CSR performance and the dissemination of positive messages through activities such as media relations.

This view is also echoed by scholars in our own field. L'Etang (1996) originally led the charge by noting that because of PR's representational role and responsibility for managing relationships it has extended its strategic scope and become associated with CSR but, "it is often managed by public relations practitioners for PR ends" (p. 90). As a result, CSR tends to be viewed as just another technique in the PR portfolio to help establish relationships with particular stakeholders and to signal messages to other groups in society.

\section{An opportunity for reconfiguration}

These issues provide an opportunity for PR practitioners and academics to work together to consider how the social auditing process might be reconfigured to take better account of an organisation's power and its impact on stakeholders. It is proposed that the practiceorientated focus of social auditing provides a framework through which the issues around power and governance that have been highlighted can start to be addressed by the application of critically driven public relations insights. This requires working with perspectives from both research and the profession to explore approaches that can start to move scholarly focus in the field from critical discourse to practical action and impact.

Such collaboration is important given the need for expanded interactions between both sides of what might be characterised as a divided discipline. Furthermore, the issue of how organisations should more actively consider the implications of their power footprint is ripe for collaboration. It is what Rittel and Webber (1973) would frame as a wicked rather than a tame problem. That is, an intractable issue that has no "right" or "wrong" answer and which benefits from being considered from a range of different perspectives. As Grint (2005) notes the way through wicked problems "is to ask the right questions rather than provide the right answers because the answers may not be self-evident and will require a collaborative process to make any kind of progress" (p. 1473, italics in original).

To meet this challenge the article introduces the idea of critical social auditing to provide a new focus for debate and reflection. This concept is informed by the idea that rather than being an activity associated with reporting and administrative compliance, social auditing needs to be more directly concerned with promoting values driven behaviour and progressive learning linked to how the organisation actually exercises power in the stakeholder environment.

\section{Creating a knowledge commons through action research}


The collaborative ethos of action research provides a methodological framework that can usefully underpin this process. Indeed, the dialogic character of action research has the potential to create a knowledge commons about how PR might engage with the issue of organisational power that can inform both theory and practice. Reason and Bradbury (2008) note that action research is a family of practices that seek "to create positive participative communities of enquiry in which qualities of engagement, curiosity and question posing are brought to bear on significant practical issues" (p. 1). Within such projects, communities of action evolve to address questions and issues that are significant for those who participate as co-researchers. Typically, such communities engage in systematic cycles of action and reflection and these characteristics mean that action research is based on a different paradigm to conventional academic research. It has different purposes, is based in different relationships, has different ways of conceiving knowledge and relates to practice differently (Reason and Bradbury, 2008).

These attributes complement the previous call for reconfiguration, particularly the generation of knowledge that can begin to address organisational power and which can be applied by people in the everyday conduct of their working lives. A cycle of learning is created in which key insights from theoretical research can inform engagement with practitioners, while the practitioner engagement has the potential to generate insights that can inform the conceptual development of critical social auditing.

Action research also has an affinity with complex, wicked problems. Many of the researchers considering complexity in a management context promote the benefits of an action research perspective. For example, Allen and Boulton's (2011) concern with uncertainty in a complex environment intersects with an action research orientation: "emphasis is placed on staying with the actual experience of what is, on focusing on the particularity of an actual, living situation and working with all the variation and all the uncertainty that is present” (p. 169). As a living, emergent process action research is well suited to an investigation of organisational power. The research process is able to change and develop as participants deepen their understanding of the issues that need to be addressed, as well as developing their capacity as co-inquirers both individually and collectively. MacLean and MacIntosh (2011) further note that all management research, particularly action research, "might be seen as a complex and unpredictable dynamic whose practices, processes and outcomes emerge from the conduct of the research as it proceeds and which can neither be specified in advance nor controlled to any great degree” (p. 235).

\section{Summary}

This paper argues that public relations research and practice have yet to systematically address the complexities associated with organisational governance in the context of stakeholder engagement. It is acknowledged this is a problematic area given it populates the realm of covert, as opposed to, overt accountability. Indeed, its focus on values falls beyond the rubric of legal compliance and regulation and relies instead on self-governance, selfreflection and self-restraint on behalf of the organisation.

In the public relations literature great emphasis is placed on the role of dialogue in helping to manage the social contract that exists between an organisation and its stakeholders. While this is crucial to organisational governance it is beset by empirical challenges. This is highlighted in the article through a discussion of dark dialogue and the introduction of the idea of passive aggression to public relations practice. While the study of dialogue focusses 
on explicit, observable action, passive aggression shows that subterranean inaction can be a powerful weapon used by organisations to disadvantage stakeholders.

It is then noted that an inability to confront issues around organisational power is an endemic problem not just in PR but in the wider management literature that is concerned with how organisations discharge their responsibilities to society. How organisations behave towards their stakeholders is a particular blind spot and this is further illustrated by the absence of social auditing protocols that specifically address how organisations exhibit power over others. To meet this challenge it is suggested that public relations practitioners and academics have an opportunity to work together to reconfigure social auditing from an activity largely concerned with reporting and administrative compliance, to a process that promotes organisational learning and progressive values based behaviour within the organisation.

\section{References}

Allen, P., \& Boulton, J. (2011). Complexity and limits to knowledge: The importance of uncertainty. In P. Allen, S. Maguire \& B. McKelvey (Eds.), The SAGE handbook of complexity and management (pp. 164-181). London: Sage.

Bendell, J. (2004). Barricades and boardrooms: A contemporary history of the corporate accountability movement, Programme Paper 13, Geneva, Switzerland: United Nations Research Institute for Social Development.

Berger, B. K. (2005). Power over, power with, and power to public relations: Critical reflections on public relations, the dominant coalition and activism. Journal of Public Relations Research, 17, 5-28.

Blowfield, M. E. (2005). Corporate social responsibility: The failing discipline and why it matters for international relations. International Relations, 19(2), 173-91.

Blowfield, M. E., \& Murray, A. (2008). Corporate responsibility: A critical introduction. Oxford: Oxford University Press.

Bowen, S. A. (2008). A state of neglect: Public relations as corporate conscience or ethic counsel. Journal of Public Relations Research, 20: 271-296.

Davenport, K. (1997). Social auditing: The quest for corporate social responsibility. In J. Weber \& K. Rehbein (Eds.), Proceedings of the International Association of Business and Society, 208-213. Florida: Destin.

Edelman Trust Barometer (2013). Downloaded on 08/05/13 http://www.edelman.com/trust2013

Edwards, L. (2006). Rethinking power in public relations. Public Relations Review 32, No. 3(2006), 229-231.

Elkington, J. (1998). Cannibals with forks: The triple bottom line for $21^{\text {st }}$ century business. Gabriola Island, Canada: New Society Publishers.

Fawkes, J. (2010). The shadow of excellence: A Jungian approach to public relations ethics. Review of Communication, 10(3), 221-227. 
Freeman, R. E. (1984). Strategic management: A stakeholder approach. Boston, MA: Pitman/Ballinger (Harper Collins).

Freeman, R. E., Harrison, J. S., Wicks, A. C., Parmar, B., \& de Colle, S. (2010). Stakeholder theory: The state of the art. Cambridge, England: Cambridge University Press.

Friedman, A. L., \& Miles, S. (2006). Stakeholders: Theory and practice. Oxford: Oxford University Press.

Gregory, A., \& Willis, P. (2013). Strategic public relations leadership. London: Routledge.

Grint, K. (2005). Problems, problems, problems: The social construction of leadership. Human Relations, 58(11), 1467-1494.

Grunig, L., Grunig, J., \& Dozier, D. (2002). Excellent public relations and effective organisations. A study of communication management in three countries. Mahwah, NJ: Lawrence Erlbaum Associates.

Grunig, J. E., \& Repper, F. C. (1992). Strategic management, publics and issues. In J. E. Grunig (Ed.), Excellence in public relations and communication management (pp. 117-157). Hillsdale, NJ: Lawrence Erlbaum Associates.

Heath, R., Toth, E., \& Waymer D. (Eds.). (2009). Rhetorical and critical approaches to public relations II. New York, NJ: Routledge.

Holtzhausen, D. (2007). Activism. In E. Toth (Ed.), The future of excellence in public relations and communication management (pp. 357-379). Mahwah, NJ: Lawrence Erlbaum Associates.

Jones, T. M. (1980). Corporate responsibility revisited, redefined. California Management Review, 22(3), 59-67.

Kent, M., \& Taylor, M. (2002). Toward a dialogue theory of public relations. Public Relations Review, 28, 21-37.

Kent, M., Taylor, M., \& McAllister-Spooner, S. (2008). Research in dialogic theory and public relations. A revised version of Kent and Taylor (2002). Retrieved from http://facultystaff.ou.edu/K/Michael.L.Kent-1/DFs/Kent_Taylor_McAllister_Dialogue_2008.pdf.

Lane, C. (2009). The surprising history of passive aggressive personality disorder. Theory and Psychology, 19(1), 55-70.

Leitch, S., \& Neilson, D. (2001). Bringing publics into public relations. New theoretical frameworks for practice. In R. Heath (Ed.), Handbook of public relations (pp. 127-138). London: Sage.

L'Etang, J. (1996). Corporate responsibility and public relations ethics. In J. L'Etang \& M. Pieczka (Eds.), Critical perspectives in public relations (pp. 82-105). London: Thomson Business Press. 
L’Etang, J., \& Pieczka, M. (Eds.) (1996), Critical perspectives in public relations. London: Thomson Business Press.

Lukes, S. (2005). Power a radical view. Basingstoke, England: second expanded edition by Palgrave Macmillan.

MacLean, D., \& MacIntosh, R. (2011). Organizing at the edge of chaos: Insights from action research. In P. Allen, S. Maguire \& B. McKelvey (Eds.), The SAGE handbook of complexity and management (pp. 235-253). London: Sage.

McKie, D. (2010). Signs of the times: Economic sciences, futures and public relations. In R. Heath (Ed.), SAGE handbook of public relations (pp. 85-97). Thousand Oaks, CA: Sage.

McKie, D., \& Munshi, D. (2007). Reconfiguring public relations: Ecology, equity and enterprise. London: Routledge.

Macnamara, J. (2012). Public Relations: Theories, practices and critiques. Frenchs Forest, Australia: Pearson.

Newell, P. (2005). Citizenship, accountability and community: The limitations of the CSR agenda. International Affairs, 81(3), 541-58.

Pieczka, M. (2011). Public relations as dialogic expertise? Journal of Communication Management, 15(2), 108-124.

Preston, L. E. (Ed.) (1988). Research in corporate social performance and policy. Greenwich, CT: JAI Press.

Reason, P., \& Bradbury, H. (2008). Introduction. In P. Reason \& H. Bradbury (Eds.), Action research: Participatory inquiry and practice (pp. 1-10). London: Sage.

Rittel, H. \& Webber, M. (1973). Dilemmas in a general theory of planning. Policy Sciences, 1973, 4, 155-169.

Spreckley, F. (1981). Social audit - A management tool for co-operative working. Leeds, England: Beechwood College.

Waddock, S. (2001). The multiple bottom lines of corporate citizenship: Social investing, reputation and responsibility audits. Business and Society Review, 105, 323-345.

Wood, D. J. (1991). Corporate social responsibility revisited. Academy of Management Review, Vol. 16(4), 691-718. 